\title{
Meckel-Gruber syndrome patient cells exhibit alterations in cell-substrate interaction, deformation response, and gene expression consistent with defects leading to liver fibrosis
}

\author{
B Meadows, ${ }^{*}$ H Dawe
}

From Cilia 2014 - Second International Conference

Paris, France. 18-21 November 2014

\section{Objective}

Meckel-Gruber syndrome (MKS) is a lethal ciliopathy characterised by CNS malformations, cystic kidneys, polydactyly, and liver fibrosis. Most of these can be explained by disruption of cilium-dependent signalling pathways. However, the aetiology of liver fibrosis is less well-understood. We hypothesised that alterations in cell-substrate interaction, ECM organisation, dysregulated secretion and ECM organisation are upstream of fibrosis in MKS.

\section{Methods}

We used a combination of imaging, biophysics and RNASeq expression analysis to study alterations in cell adhesion and matrix composition in neonatal fibroblasts isolated from patients with mutations in MKS2 (TMEM216) or MKS3 (TMEM67), alongside age-matched controls.

\section{Results}

We found that MKS cells exhibit striking differences in spreading morphology on ECM substrates in comparison to controls. While $M K S 2$ cells spread faster than controls on all substrates examined, MKS3 cells showed a substrate-specific increase in spreading on collagen IV. We also observed differences in the morphology and distribution of focal adhesions, which appeared more mature and pervasive. Of the $\sim 3000$ genes with altered expression levels in $M K S$ cells, those associated with ECM components as well as fibrosis-implicated upstream effectors of ECM organisation and cell-substrate signalling were highly over-represented. These

Biosciences, Lab 211, Dawe Group, University of Exeter, Exeter, UK

differences were consistent with those reported in other studies of liver fibrosis. Finally, MKS cells were less resistant to deformation and fragmentation under externally applied pressure.

\section{Conclusions}

We propose that a combination of defective regulatory signalling and excess ECM deposition, together with changes to cortical integrity and/or plasma membrane tension may contribute to the fibrotic pathology observed in patients.

Published: 13 July 2015

doi:10.1186/2046-2530-4-S1-P58

Cite this article as: Meadows and Dawe: Meckel-Gruber syndrome patient cells exhibit alterations in cell-substrate interaction, deformation response, and gene expression consistent with defects leading to liver fibrosis. Cilia 2015 4(Suppl 1):P58.

Submit your next manuscript to BioMed Central and take full advantage of:

- Convenient online submission

- Thorough peer review

- No space constraints or color figure charges

- Immediate publication on acceptance

- Inclusion in PubMed, CAS, Scopus and Google Scholar

- Research which is freely available for redistribution 